\title{
EFFECT OF DIETARY METHIONINE ON GROWTH AND UTILIZATION OF CLARIAS GARIEPENIUS FINGERLINGS
}

\author{
*Aliu B.S. and Omenogor S.O. \\ *Department of Fisheries, University of Benin, Benin-City, Nigeria. \\ Email: bayo.aliu@uniben.edu Phone no: +2348055314843 \\ *Corresponding Author
}

\begin{abstract}
The growth response and feed utilization of Clarias gariepinus fed with diet containing different level of dietary synthetic methionine was investigated to determine the effect of diet on their growth rate and its utilization by fish. (108) fingerlings of Calrias gariepinus $(2.1 \pm 0.5 \mathrm{~g})$ obtained from a private fish farm in Benin City were stocked in eighteen (18) $25 \mathrm{~L}$ plastic tank. 6 diet (40\%) crude protein consisting of a control $10 \%$ methionine supplementation) and five DIT other diet (3.2\%, 4.23\%, 7.30\%, 8.70\% and 9.79\% synthetic methionine supplementation) were compounded and fed to the fish till satiation. Each diet was fed to the fish twice daily (9.00hrs and 17.00hrs). Data on the weight gain and feed consumed were taken on weekly basis. There was no significant difference in term of relative weight gain (RWG), specific growth rate (SGR), total weight gain (TWG) and weekly weight gain (WWG). The control with $(0 \%$ methionine) showed a higher weight gain with diet 5 (8.76\% methionine) having a lower weight gain. However, the feed intake (FI) was significantly different $(P<0.005)$ with the control midway the highest feed intake but diet 2 $(4.25 \%)$ with a step downward showed lowest feed intake. The protein efficiency ratio (per) value were significantly different with diet 1 having the highest value which was different from all other which with diet 4 having a lowest per. In terms of survival there was significant difference $(P<0.05)$ with diet 3(0\% methionine). Supplementation has the highest and a reduced survival at diet 2 synthetic methionine. In this study synthetic methionine had not been sufficiently utilized by Clarias gariepinus fingerling since the control did perform better than those supplemented with various level of methionine
\end{abstract}

Keywords: Clariid catfish, Clarias gariepinus, fingerlings, optimum energy, protein levels, fish diet. 


\section{Introduction}

The national fish demand is about 1.85 million tons while the local production is only 0.51 million tonnes, based on a population figure of 140 million people (Ovie and Raji, 2006). Nigeria currently imports 0.7 million tons of frozen fish annually making it the highest importer of frozen fish in the world with annual foreign exchange drain of 35 billion naira (Federal Department of Fisheries, (FDF), 2005). The challenge therefore is to bridge the wide gap between fish demand and supply within the shortest possible time. Aquaculture has been acknowledged as a viable tool in bridging the gap and efficient means of providing food fish which is rich in protein to the populace (Milla, 2003). Though is been faced with the problem of inadequate supply and prohibitive cost of quality fish feeds.

Feed, one of the most important and expensive factor in fish production, it accounts for up to about $70 \%$ of the variable cost of production in aquaculture (Rawles et al., 2011). Thus in feed formulation the present trend and most beneficial is to consider least-cost, with low fish meal and high level of plant proteins and supplementation with amino acid in feed to meet the nutritional requirement of catfish and also translate to more profit for the culturist. The nutrition requirements of fish are similar to those of animals. For growth, reproduction and other normal physiological functions, they need to consume proteins, minerals, vitamins and growth factor and energy sources (Lovell, 2000). It was also stated that a deficiency of one or more of the essential nutrients may result in a reduced rate of performance, disease or even death.

\section{Materials and Methods}

This study was carried out in the main laboratory, Faculty of Agriculture, University of Benin, Benin City, Edo State, Nigeria between September and November 2014. The experiment was conducted to determine the utilization and consequent growth response of Clarias gariepinus fingerlings to synthetic amino acid, methionine.

\section{Experimental Diets and Feeding Regime}

Six diets of $40 \%$ crude protein were compounded from locally available feed stuff which include yellow maize, fish meal, palm oil, bone meal vitamin premix, soyabean meal, vitamin E gel, the ingredients were finely milled before mixing and the feeds were prepared from the gross composition. The fishes were fed diets which had ingredients that have been supplemented with synthetic methionine. A control diet containing no synthetic methionine was formulated. Vitamin premix was added to each diet to provide the needed vitamins for normal growth and also vitamin $\mathrm{E}$ gel was added to prevent oxidation. The diets were pelleted and dried using the charcoal oven. Feeding was done twice a day (between the hours of 9: am and 5: $\mathrm{p} \mathrm{m}$ ) for a period of 42 days. 
Table 1: $\quad$ Gross Composition of Experimental Diets

\begin{tabular}{|c|c|c|c|c|c|c|}
\hline Ingredients & $\begin{array}{l}\mathrm{D}_{1} \\
3.2 \% \\
\text { methionine }\end{array}$ & $\begin{array}{l}\mathrm{D}_{2} \\
4.23 \% \\
\text { Methionine }\end{array}$ & $\begin{array}{l}D_{3} \\
\text { Control }\end{array}$ & $\begin{array}{l}\mathrm{D}_{4} \\
7.30 \% \\
\text { Methionine }\end{array}$ & $\begin{array}{l}D_{5} \\
8.76 \% \\
\text { methionine }\end{array}$ & $\begin{array}{l}\mathrm{D}_{6} \\
9.79 \% \\
\text { methionine }\end{array}$ \\
\hline Methionine & 3.20 & 4.23 & - & 7.30 & 8.76 & 9.79 \\
\hline Fish meal & 25.00 & 25.00 & 25.00 & 25.00 & 25.00 & 25.00 \\
\hline $\begin{array}{l}\text { Soya bean } \\
\text { cake }\end{array}$ & 50.80 & 49.77 & 54.00 & 46.70 & 45.24 & 44.21 \\
\hline $\begin{array}{l}\text { Yellow } \\
\text { maize }\end{array}$ & 5.00 & 5.00 & 5.00 & 5.00 & 5.00 & 5.00 \\
\hline Groundnut & 8.36 & 8.36 & 8.36 & 8.36 & 8.36 & 8.36 \\
\hline Bone meal & 4.00 & 4.00 & 4.00 & 4.00 & 4.00 & 4.00 \\
\hline $\begin{array}{l}\text { Vitamin } \\
\text { pre mix }\end{array}$ & 0.60 & 0.60 & 0.60 & 0.60 & 0.60 & 0.60 \\
\hline Vitamin E & 0.04 & 0.04 & 0.04 & 0.04 & 0.04 & 0.04 \\
\hline $\begin{array}{l}\text { gel } \\
\text { Total }\end{array}$ & 100 & 100 & 100 & 100 & 100 & 100 \\
\hline
\end{tabular}

Table 2: $\quad$ Proximate Composition of Experimental Diets. (\%)

\begin{tabular}{llllllll}
\hline Diets & $\begin{array}{l}\% \\
\text { Moisture }\end{array}$ & $\begin{array}{l}\text { \% Crude } \\
\text { Protein }\end{array}$ & $\begin{array}{l}\text { \% } \\
\text { Lipid }\end{array}$ & Crude & \% Ash & $\begin{array}{l}\text { \% Crude } \\
\text { Fibre }\end{array}$ & \% NFE \\
\hline Diet I & 10.10 & 41.50 & 30.30 & $8 . .20$ & 5.21 & 4.69 \\
& & & & & & \\
Diet II & 15.20 & 45.5 & 20.10 & 8.31 & 4.68 & 6.21 \\
Diet III & 15.30 & 19.25 & 30.20 & 8.41 & 5.42 & 21.42 \\
Diet IV & 10.00 & 38.5 & 30.40 & 8.75 & 4.37 & 7.98 \\
Diet V & 10.10 & 51.75 & 20.42 & 8.00 & 5.71 & 4.02 \\
Diet VI & 10.20 & 42.00 & 20.71 & 8.32 & 5.13 & 13.64
\end{tabular}

\section{Experimental Fish}

A total of two hundred (200) Clarias garipenius fingerling was obtained from Dr Joe fish farm in Benin City. The fingerlings were stocked in (18) plastic tanks (25L) rectangular in shape measuring $6 \mathrm{~m}$ by $4 \mathrm{~m}$ with a transparent colour. Each of the plastic tanks was stocked with 6fishes; with an average initial weight of $2.12 \mathrm{~g}$. Each treatment was in three replicate in randomised complete design of (3 by 6 ).

\section{Management Practice}

The water was changed once every morning. Changing of the water was done prior the feeding times in the morning. After each feeding in the morning and evening, say $15-20$ minutes, the unconsumed feeds were removed by siphoning them out of the glass tanks into a drainage channel on the floor of the laboratory. Once every week, total changing of the water, washing of the tanks, weighing of the fingerlings and extermination of feed consumed were carried out. This helps to keep the water temperature, $\mathrm{pH}$, dissolved oxygen, ammonia and nitrate under control. 


\section{Growth Performance and Feed Utilization Parameters}

Means of weight gain, percentage weight gains and specific growth rate (SGR\% in days) were calculated using the following equations:

1. Weight gain $=\mathrm{W}_{1}-\mathrm{W}_{0}$

2. Relative Weight Gain $(\mathrm{RWG} \%)=\left(\underline{\mathrm{W}}_{\frac{1}{\mathrm{~W}_{0}}}-\mathrm{W}_{0}\right) \times \frac{100}{1}$

\section{Specific Growth Rate $(\mathrm{SGR} \%)=\frac{\left(\mathrm{l}_{\mathrm{n}} \mathrm{W}_{1}-\mathrm{l}_{\mathrm{n}} \mathrm{W}_{0}\right)}{\mathrm{T}} \times \frac{100}{1}$}

Where:

$\mathrm{W}_{0}=$ Mean initial weight $(\mathrm{g})$

$\mathrm{W}_{1}=$ Mean final weight $(\mathrm{g})$

$\mathrm{T}=$ Time in days between weightings

Feed Conversion Ratio (FCR), Protein Efficiency Ratio (PER) and Net Protein Value (NPV $\%$ ) were also calculated according to the following equations:
1. Feed Conversion Ratio (FCR) =
Feed intake $(\mathrm{g})$
Weight gain $(\mathrm{g})$

\section{Protein Efficiency Ratio $(\mathrm{PER})=$ Weight gain $(\mathrm{g})$ Protein intake $(\mathrm{g})$}

\section{Sampling}

Sampling was carried out on weekly basis by weighing the whole fish in each replicate using the digital weighing scale. On each sampling day, complete replacement of water was carried out, while on the rest days unconsumed feeds and faecal wastes were siphoned out of the culture water with the use of hose (partial replacement of water).

\section{Chemical Analyses}

Analyses of the experimental formulated diet and whole fish body (initial carcass) were carried out for Moisture Content, Nitrogen, Ether Extract, Crude Fibre and Nitrogen Free Extract (NFE) i.e. the energy content according to the procedures of Association of Official Analytical Chemist (A. O. A. C, 2000) using triplicate samples for each determination, crude protein was calculated as Nitrogen Content X 6.25.

\section{Statistical Analysis}

The statistical analysis was computed by using analysis of variance procedure through the help of a software called Genstat. The significant mean differences between treatment means were separated by Duncan's Multiple Range Test (Duncan, 1955). 


\section{Result}

The result obtained in the study is shown in Table 3 below.

Table 3: Growth Performance and Feed Utilization Parameters of C.gariepinus Fingerlings fed with methionine fortified diet at various levels

\begin{tabular}{|c|c|c|c|c|c|c|c|}
\hline Parameters & $\begin{array}{l}\text { T1 } \\
3.2 \%\end{array}$ & $\begin{array}{l}\mathrm{T} 2 \\
4.23 \%\end{array}$ & $\begin{array}{l}\text { T3 } \\
5.26 \%\end{array}$ & $\begin{array}{l}\text { T4 } \\
7.30 \%\end{array}$ & $\begin{array}{l}\text { T5 } \\
8.76 \%\end{array}$ & $\begin{array}{l}\text { T6 } \\
9.79 \%\end{array}$ & SEM \\
\hline $\begin{array}{l}\text { Relative weight gain } \\
\text { (RWG) (g) }\end{array}$ & 55.7 & 51.2 & 67.4 & 49.7 & 49.2 & $57.4^{\mathrm{NS}}$ & 9.23 \\
\hline Feed Intake (FI) (g) & $3.801^{\mathrm{a}}$ & $3.543^{\mathrm{a}}$ & $4.463^{b}$ & $4.383^{\mathrm{b}}$ & $3.779^{\mathrm{a}}$ & $3.991^{\mathrm{ab}}$ & 0.26 \\
\hline $\begin{array}{l}\text { Feed conversion } \\
\text { ratio }(F C R)\end{array}$ & 2.73 & 1.70 & 2.3 & 4.62 & 1.47 & $1.30^{\mathrm{NS}}$ & 3.82 \\
\hline $\begin{array}{l}\text { Specific Growth rate } \\
\text { (SGR) }\end{array}$ & 5.9 & 4.2 & 7.3 & 2.9 & 4.9 & $6.1^{\mathrm{NS}}$ & 4.92 \\
\hline $\begin{array}{l}\text { Protein efficiency } \\
\text { ratio (PER) }\end{array}$ & $10.58^{\mathrm{a}}$ & $4.85^{\mathrm{b}}$ & $4.88^{\mathrm{b}}$ & $3.89^{\mathrm{b}}$ & $4.58^{\mathrm{b}}$ & $4.86^{\mathrm{b}}$ & 2.42 \\
\hline Survival rate (SR) & $72.2^{\mathrm{ab}}$ & $63.8^{\mathrm{a}}$ & $81.5^{\mathrm{b}}$ & $79.6^{\mathrm{b}}$ & $75.0^{\mathrm{ab}}$ & $84.3^{\mathrm{b}}$ & 6.48 \\
\hline $\begin{array}{l}\text { Total weight gain } \\
\text { (TWG) (g) }\end{array}$ & 6.88 & 4.99 & 6.95 & 5.57 & 5.82 & $6.16^{\mathrm{NS}}$ & 1.35 \\
\hline $\begin{array}{l}\text { Weekly weight gain } \\
\text { (WWG) (g) }\end{array}$ & 15,54 & 12.78 & 16.24 & 13.02 & 13.30 & $14.79^{\mathrm{NS}}$ & 1.67 \\
\hline
\end{tabular}

Values with the same superscript on the same row are not significantly different (p>0.05)

There was no significant different $(\mathrm{p}>0.05)$ in relative weight gain $(\mathrm{RWG})$ in Diet 1 to Diet 6 with supplementation level of $(3.2 \%, 4.23 \%, 7.30 \%, 8.76 \%$ and $9.79 \%)$ but it was observed that Diet 3 (control) had a higher relative weight gain with diet 5 (8.76\% methionine supplementation) having lower relative weight gain meaning that there is a depression in relative weight gain (RWG).

In terms of feed intake(FI), there was significant different $(\mathrm{p}<0.05)$ in the level of feed intake with Diet 3 (control) and Diet 4 (7.30\% methionine) having the highest feed intake but there was decrease in feed intake as the level of supplementation increase with Diet 2 having the least feed intake.

There was no significant different in Diet 1 to Diet 6 with inclusion level of (3.2\% to 9.79\%) but it was observed that Diet $6(9.79 \%)$ had the lowest feed conversion ratio(FCR) meaning that Diet 6 turn more feed to flesh.

There was no significant different $(p>0.05)$ in the specific growth rate (SGR), but Diet 3 (control) had a high value for specific growth rate with Diet 4 (7.30\% methionine) having the least growth rate meaning the higher inclusion level of methionine the less the growth rate become.

Diet $1(3.2 \%)$ methionine had a high protein efficiency ratio (PER) which is significantly different $(\mathrm{p}<0.05)$ from Diets 2,3,4,5 and 6, meaning that the protein efficiency ratio increase with reduced methionine supplementation. 
From the table, Diet 6 (9.79) had a higher survival rate which is significantly different from other Diets followed by 3 (control), meaning that there was a high survival with increasing level of supplementation.

There was no significant different in $(\mathrm{p}>0.05)$ in total weight gain and weekly weight gain in Diet 1 to Diet 6 but diet 3 (control) had a higher value for total weight gain and weekly weight gain, meaning diet with no supplementation had a tendency to have a more weight gain since an increase in supplementation lead to depression in weight.

\section{Discussion}

The result showed that there was no significant difference in the growth of fish fed varying levels of synthetic methionine and the control diet (T3) which indicates that $C$. gariepinus grows appreciably with feed of low biological value. This result is similar to the study carried out on C. gariepinus fingerlings by Eyo and Olatunde (1998); Ruchimatet al.(1997) on Seriola quinqueradiata. When the growth of fish of all diets containing synthetic methionine is compared with the fish fed the reference diet, the latter is superior, an indication of the bioavailability of the essential amino acid than that of the experimental diet.

This result differs from earlier experiment carried out with $C$. gariepinus fingerlings by Ovie and Eze, (2009). In fingerling experiments, the regression graphs had maxima at $2.97 \mathrm{~g}$ methionine/100 protein. This is similar to the observation for channel catfish by Ahmed et al. (2006) for Cirrhinus mrigala by Zhou et al. (2006) for Epinephelus coioides by Ruchinat et al. (1997) and Twibell et al. (2000), for Seriola quinqueradiata; Harding et al. (1977) for Anguilla japonicus and Cyprinus carpio; Santaigo and Lovell (1988) for O. niloticus, Borlongan and Coloso (1993) for Chanos chanos; Jackson and Capper (1982) for $S$. mossambicus; Keembiyehetty and Gatlin (1993) for hybrid striped bass; Moon and Gatlin, (1991) for Sciaenops ocellatus; Nose, (1979) for Carp. However, this does not compare well with the observation for red sea bream Pagrus major, whose amino acid requirement changed with growth and or age (Takagi et al., 2001).

\section{Conclusion}

The fact that there was no significant difference $(p>0.05)$ between the control and other diets in survival rate, relative weight gains, total weight gain indicates that the fingerling (Claris garipenius) response to feed did not change with inclusion of synthetic methionine. 


\section{References}

Ahmed Imtiaz, Khan Mukhtar A, Jafri AK, Dietary methionine requirement of fingerling Indian major carp, Cirrhinus mrigala (Hamilton). Aquaculture International, Springer Netherlands 2006; 11: 449 - 462 [2]

Association of official analytical chemists (AOAC). (2000): Official methods of analysis. Arlington Virginia.

Borlongan I.G., and Coloso, R.M., (1993): Requirements of juvenile milkfish (Chanos chanos Forsskai) for essential amino acids. J.Nutr. 123: 125-132.

Eyo, A.A and Olatunde, A.A. (1998): Effect of Supplementation of soybean diet with Llysine and L-methionine on the growth of mud-catfish $C$. anguillaris fingerlings. Nigeria Journal of Biotechnology, 9(1): 9 - 16.

Federal Department of Fisheries, (FDF). (2005). Report of presidential committee on Fisheries and aquaculture development (vol. 1): Consolidated report, Federal Department Of Fisheries, Ministry Of Agriculture and Rural Development . September, 2005

Harding DE, Allen OW, and Wilson RP, (1977): Sulphur amino acid requirement of Channel catfish: L- methionine and L-cystine. Journal of Nutrition; 107: 2031-2035.

Jackson AJ, Capper BS, (1982): Investigation into the requirements of the tilapia Sarotherodonmossambicus for dietary methionine, lysine and arginine in semisynthetic diets.Aquaculture; 29: 289-297.

Keembiyehetty CN, Gatlin DM, (1993): Total sulphur amino acid requirement of juvenile striped bass (Moronechrysops x M. saxatillis). Aquaculture;110:331- 339

Lovell, R.T. (2000). Factors affecting voluntary food consumption by channel catfish. Proceedings of the Annual Conference of the Southern Association of Fish and Wildlife Agencies.33: pp563- 571

Milla, J. (2003): Aquaculture Professional Organization: The Future of Nigeria's Aquaculture industry is in your hands. Fisheries Society of Nigeria (FISON) conference proceedings. Ed. Eyo A.A and Ayanda J.O, pp. 5-6

Moon HY, Gatlin DM, (1991): Total sulphur amino acid requirement of juvenile red drum, Sciaenops ocellatus. Aquaculture; 95:97-106

Nose T, (1979): Summary report on the requirements of essential amino acid for carp. In: Finfish Nutrition and Fishfeed Technology (Tiews, K. and Halver, J. E., eds.), ; pp. 145-156. Heenemann GmbH, Berlin, Germany.

Ovie So, Eze S, Methionine requirement of C. gariepinus fry and its effect on the body composition. In press

Rawles, S.D., Thompson, K.R., Twibell, R.G., Gannam, A.L. and Webster, C.D. (2011). Effects of replacing fish meal with poultry by-product meal, soybean meal and reduced protein level on the performance and immune status of pond- grown marine sunshine bass (Moronechrysops $x$ M. saxatilis) and fresh water catfish, (Clarias gariepinus). Aquaculture Nutrition 17: pp 708- 721 
RuchinatTni, Masumoto Toshiro, Hosokawa Hidetsuyo, SimenoSadao, (1997) Quantitative methionine requirement of yellowtail (Seriola quinqueradiata). Aquaculture; 150: $113-122$.

Twibell Ronald G, Wilson Keith A, Brown Paul B, (2000): Dietary sulphur amino acid requirement of juvenile yellow perch fed the maximum cystine replacement value for methionine. Journal of Nutrition; 130: 612-615

Zhou Qi-Cun, Wu Zao-He, Tan Bei-Ping,ChiShu-Yan and Yang Qi-Hui (2006). Optimal dietary methionine requirement for juvenile Cobia (Rachycetron canadum). Aquaculture 2006; 258: 551-557 